\title{
Incremental amounts of Ascophyllum nodosum meal do not improve animal performance but do increase milk iodine output in early lactation dairy cows fed high-forage diets ${ }^{1}$
}

\author{
N. T. Antaya, ${ }^{\star}$ K. J. Soder,† J. Kraft,‡ N. L. Whitehouse, ${ }^{*}$ N. E. Guindon, ${ }^{*}$ P. S. Erickson, ${ }^{\star}$ A. B. Conroy, $§$ \\ and A. F. Brito*2 \\ ${ }^{*}$ Department of Biological Sciences, University of New Hampshire, Durham 03824 \\ †Pasture Systems and Watershed Management Research Unit, USDA-Agricultural Research Service, University Park, PA 16802 \\ ‡Department of Animal Science, University of Vermont, Burlington 05405 \\ $\S$ Thompson School of Applied Science, University of New Hampshire, Durham 03824
}

\section{ABSTRACT}

The objective of this study was to investigate the effects of incremental amounts of Ascophyllum nodosum meal (ANOD) on milk production, milk composition including fatty acids and I, blood metabolites, and nutrient intake and digestibility in early lactation dairy cows fed high-forage diets. Twelve multiparous Jersey cows averaging (mean \pm standard deviation) $40 \pm 21 \mathrm{~d}$ in milk and $464 \pm 35 \mathrm{~kg}$ of body weight and 4 primiparous Jersey cows averaging $75 \pm 37 \mathrm{~d}$ in milk and $384 \pm 17$ $\mathrm{kg}$ of body weight were randomly assigned to treatment sequences in a replicated $4 \times 4$ Latin square design. Each period lasted $21 \mathrm{~d}$ with $14 \mathrm{~d}$ for diet adaptation and $7 \mathrm{~d}$ for data and sample collection. Cows were fed a total mixed ration (64:36 forage-to-concentrate ratio) supplemented (as fed) with $0,57,113$, or $170 \mathrm{~g} / \mathrm{d}$ of ANOD. Milk yield as well as concentrations and yields of milk components (fat, protein, lactose, milk urea $\mathrm{N}$ ) were not affected by increasing dietary amounts of ANOD. Concentration (from 178 to $1,370 \mu \mathrm{g} / \mathrm{L}$ ) and yield (from 2.8 to $20.6 \mathrm{mg} / \mathrm{d}$ ) of milk I increased linearly in cows fed incremental amounts of ANOD as a result of the high concentration of I $(820 \mathrm{mg} / \mathrm{kg}$ of dry matter) in ANOD. Overall, only minor changes were observed in the proportion of milk fatty acids with ANOD supplementation. Quadratic trends were observed for dry matter intake and total-tract digestibilities of organic matter and neutral detergent fiber, whereas negative linear trends were observed for serum concentration of cortisol and crude protein digestibility with ANOD supplementation. Serum concentrations of triiodothyronine and thyroxine were not affected by ANOD supplementation and averaged 1.1 and $48.4 \mathrm{ng} /$

Received September 12, 2014.

Accepted November 10, 2014.

${ }^{1}$ Contribution no. 2588 from the New Hampshire Agricultural Experiment Station.

${ }^{2}$ Corresponding author: andre.brito@unh.edu
$\mathrm{mL}$, respectively. However, feeding increasing amounts of ANOD linearly reduced the plasma concentration of nonesterified fatty acids (from 164 to $132 \mathrm{mEq} / \mathrm{L}$ ). Quadratic effects were found for the total-tract digestibility of ADF and urinary output of purine derivatives, suggesting that ANOD supplementation may stimulate growth of ruminal cellulolytic bacteria in a dose-dependent fashion. In general, feeding incremental amounts of ANOD to early lactation dairy cows dramatically increased milk I concentration and output with no effect on animal performance.

Key words: Ascophyllum nodosum meal, dairy cow, iodine, milk yield

\section{INTRODUCTION}

Macroalgae (commonly known as seaweed) have been used as feed supplements, soil conditioners, and as source of minerals for plants and animals since antiquity (Allen et al., 2001a). Ascophyllum nodosum is undoubtedly the macroalga species most used and researched in agricultural systems (Allen et al., 2001a). In addition to the high concentration of macro- and microminerals, $A$. nodosum is known to contain a wide spectrum of nutritional compounds, including polysaccharides, PUFA, polyphenols, bioactive peptides, and vitamins (Kumari et al., 2010; Tierney et al., 2010; Fitzgerald et al., 2011). Specifically, A. nodosum is rich in polyphenolic compounds such as phlorotannins, which are similar to terrestrial tannins in the ability to bind proteins and carbohydrates (Ragan and Glombitza, 1986) and to inhibit bacterial growth (Wang et al., 2008, 2009). Moreover, A. nodosum contains significant concentrations of antioxidants such as $\beta$-carotene and fucoxanthine (Haugan and Liaaen-Jensen, 1994), which may improve animal health (Allen et al., 2001a).

Water-soluble extracts derived from $A$. nodosum are commercially available to be used as feed additives for livestock with multiple goals, including alleviation of 
symptoms caused by endophyte-infected tall fescue [Schedonorus phoenix (Scop.) Holub] pasture grazed by ruminants (Allen et al., 2001a; Fike et al., 2001). In addition to extract products, sun-dried meals made from A. nodosum are also available commercially and are commonly used as feed additives in the livestock industry (Allen et al., 2001a).

It is well known that $A$. nodosum is an I-rich macroalga species (MacArtain et al., 2007). A dose-response relationship has been established between consumption of I and I appearance in milk of dairy cows (Franke et al., 2009; Borucki Castro et al., 2011, 2012). As a result, milk has become one of the major sources of I for humans (Dahl et al., 2003; Pearce et al., 2004). However, excess I intake has emerged as a growing public health concern, particularly for children, who are more susceptible to symptoms of I toxicity (IOM, 2001; Zimmermann et al., 2005). According to a Canadian study, more than $85 \%$ of the 60 dairy farms surveyed in the province of Quebec were overfeeding I, thus indicating that I-rich supplements such as A. nodosum meal (ANOD) should be used cautiously when formulating dairy rations (Castro et al., 2011).

Hardie et al. (2014) reported that, on average, $49 \%$ of Wisconsin organic dairy farmers who participated in a survey about the feeding strategies adopted on their farms supplement ANOD to lactating cows. Results from Hardie et al. (2014) were corroborated by N. T. Antaya (unpublished data), who assessed, through a mailed survey, that $58 \%$ of organic dairy farmers in the northeastern United States feed ANOD to lactating cows for the following reasons: (1) it improves body condition and overall animal appearance, (2) it decreases SCC, reproductive problems, and incidence of pinkeye (i.e., infectious bovine keratoconjunctivitis), and (3) it helps with fly control. Despite the remarkable popularity of ANOD use among midwestern and northeastern organic dairy farmers, previous studies showed inconsistent responses in milk yield, mitigation of heat stress, and improvement of animal health when ANOD was supplemented to dairy cows (Cvetkovic et al., 2004; Kellogg et al., 2006; Pompeu et al., 2011). Berry and Turk (1944) reported no beneficial effects on milk production and reproductive performance in dairy cattle fed giant kelp (Marcocystis pyrifera) throughout the first and second gestation. It is important to note, however, that we are not aware of studies that comprehensively evaluated the amount of ANOD that could maximize milk production, nutrient utilization, and animal health through a controlled dose-response study using early lactation dairy cows.

We hypothesized that the antimicrobial and antioxidant properties of ANOD, in addition to its high concentration of microminerals and vitamins, would improve milk production, animal health, and nutrient utilization in early lactation dairy cows fed high-forage diets. The objectives of our study were to investigate the effects of incremental dietary amounts of ANOD on milk production, milk composition including FA profile and I output, blood markers of animal health and thyroid gland function [e.g., cortisol, NEFA, triiodothyronine $\left(\mathbf{T}_{3}\right)$ and thyroxine $\left.\left(\mathbf{T}_{4}\right)\right]$, and nutrient utilization in early lactation organically certified dairy cows fed high-forage diets.

\section{MATERIALS AND METHODS}

Care and handling of the animals used in the current study were conducted as outlined in the guidelines of the University of New Hampshire Institutional Animal Care and Use Committee (Protocol no. 111002). The 84-d long experiment was conducted at the University of New Hampshire Burley-Demeritt Organic Dairy Research Farm $\left(43^{\circ} 10^{\prime} \mathrm{N}, 70^{\circ} 99^{\prime} \mathrm{W}\right)$ from November 17, 2011, to February 10, 2012. The environmental temperature ranged from -20.0 to $17.7^{\circ} \mathrm{C}\left(\right.$ mean $\left.=0.33^{\circ} \mathrm{C}\right)$ during the experiment, and was determined by hourly data from the National Climate Data Center weather station at the University of New Hampshire Kingman Farm (Durham, NH; $43.13^{\circ} \mathrm{N}, 70.98^{\circ} \mathrm{W}$ ) located approximately $12 \mathrm{~km}$ away from the experiment site.

In the current study, the $A$. nodosum meal-based product sold as organically certified kelp meal (Thorvin Inc., New Castle, VA) was used. However, because of the lack of a consistent terminology to define A. nodosum meal in the literature [e.g., kelp meal, brown seaweed meal, seaweed meal, Tasco-14 (Acadian Seaplants Ltd., Nova Scotia, Canada), and so on], the acronym ANOD will be used herein when referring exclusively to $A$. nodosum meal. This will make comparisons across studies consistent and standardized.

\section{Animals, Experimental Design, and Treatments}

Twelve multiparous Jersey cows averaging (mean \pm SD) $40 \pm 21$ DIM and $464 \pm 35 \mathrm{~kg}$ of BW and 4 primiparous Jersey cows averaging $75 \pm 37$ DIM and $384 \pm 17 \mathrm{~kg}$ of BW at the beginning of the study were used. Animals were randomly assigned to treatment sequences in a replicated $4 \times 4$ Latin square design. Distribution of animals to squares were done to balance for differences in parity and DIM, thus resulting in 3 squares of multiparous cows (square $1=20 \pm 2$ DIM; square $2=36 \pm 8 \mathrm{DIM}$; and square $3=66 \pm$ 14 DIM) and 1 square of primiparous cows (square 4 $=75 \pm 37$ DIM). Treatment sequences within each Latin square were balanced for carryover effects in subsequent periods. Each period lasted $21 \mathrm{~d}$ with $14 \mathrm{~d}$ for 
diet adaptation and $7 \mathrm{~d}$ for data and sample collection. The 4 dietary treatments consisted (as-fed basis) of 0 , 57, 113, and $170 \mathrm{~g}$ of ANOD (kelp meal; Thorvin Inc.). Whereas the 57- and 113-g doses were within the range of ANOD supplementation used in previous research (Cvetkovic et al., 2004; Kellogg et al., 2006; Pompeu et al., 2011; Karatzia et al., 2012), the 170-g dose was included to extrapolate amounts fed in previous research or recommended for lactating dairy cows by the manufacturer (i.e., Thorvin Inc.). Animals were housed in a bedded-pack barn with dried pine shavings as bedding. The bedded area $\left(132 \mathrm{~m}^{2}\right)$ opened to a $478-\mathrm{m}^{2}$ cement outdoor lot (total pen area $=610 \mathrm{~m}^{2}$ ), allowing cows to walk freely to comply with the USDA National Organic Program "Pasture Rule" (USDA-AMS, 2010), which calls for year-round access to the outdoors for all ruminant animals. A roof-covered feeding station equipped with Calan doors system (American Calan Inc., Northwood, NH) was located at the end of the outdoor lot.

The forage component of the TMR consisted of first cutting baleage harvested from 2 fields with different botanical compositions. Both fields were composed of cool season grass-legume mixtures, with field 1 containing predominantly orchardgrass (Dactylis glomerata L.) and field 2 containing predominantly alfalfa (Medicago sativa L.). Forages were cut using a flail-type mower centerline conditioner (model FC353RGC; Kuhn North America Inc., Brodhead, WI), tedded (model GA7302DL; Kuhn North America Inc.), and field-wilted to at least $45 \%$ DM attained approximately $36 \mathrm{~h}$ after cutting. Forages were then harvested as baleage using a large round baler with a crop cutter (model BR740A; New Holland Agriculture, New Holland, PA), wrapped with stretch plastic using a bale wrapper (model 991BJS; McHale Engineering Ltd., Ballinrobe, Ireland) without preservative, and stored in the field. Diets were formulated to yield a 65:35 forage-to-concentrate ratio to meet or exceed the animals' nutritional requirements for milk production using NRC (2001) ration-evaluation software. The actual ingredient composition of the TMR (DM basis) consisted of 31.8\% mixed-mostly grass baleage, $32.4 \%$ mixed-mostly legume baleage, and $35.8 \%$ concentrate. The concentrate was composed (as fed) of $11.2 \%$ soybean meal, $46.7 \%$ corn meal, $22.0 \%$ organic barley, $5.2 \%$ wheat middlings, $8.0 \%$ roasted soybean, $0.82 \%$ dicalcium phosphate (DIKAL 21; Amax Phosphate Inc., Greenwich, CT; $19 \%$ Ca and $21 \%$ P), $1.1 \%$ limestone, $1.3 \%$ sodium bicarbonate, $1.5 \%$ salt, $0.44 \%$ potassium sulfate, $0.72 \%$ magnesium oxide, $0.41 \% \mathrm{Se}$, $0.29 \%$ A-D-E vitamins premix (Cooperative Feed Dealers Inc., Conklin, NY), and $0.34 \%$ standard minerals premix (Cooperative Feed Dealers Inc.). The vitamin and mineral premixes provided (guaranteed analysis)
$6,062,721 \mathrm{IU} / \mathrm{kg}$ of vitamin $\mathrm{A}, 1,653,450 \mathrm{IU} / \mathrm{kg}$ of vitamin D, 25,353 IU $/ \mathrm{kg}$ of vitamin E, 30\% Ca, $790 \mathrm{mg} /$ $\mathrm{kg}$ of I, $675 \mathrm{mg} / \mathrm{kg}$ of $\mathrm{Co}, 6.0 \mathrm{~g} / \mathrm{kg}$ of $\mathrm{Cu}, 4.0 \%$ of $\mathrm{Zn}$, and $2.5 \%$ of $\mathrm{Mn}$.

\section{Animal Feeding and Feed Sampling and Analyses}

All bales used in the current study were sampled before feeding using a Hilti model TE 7-A drill (Hilti North America, Tulsa, OK) fitted with a metal core sampler (40 cm long). Throughout the duration of the study, baleage samples (approximately $50 \mathrm{~g}$ each) obtained after 3 to 4 core samplings from each bale were composited to yield individual sample sizes of 150 to 200 g. Concentrate samples (about $500 \mathrm{~g}$ ) were collected once weekly throughout the experiment. Baleage and concentrate samples were dried in microwave ovens (Sunbeam Digital Microwave Oven; Sunbeam Products Inc., Boca Raton, FL) with the resulting DM used to adjust the forage and concentrate proportions of the asfed TMR. Prior to the morning feeding, baleages were weighed and chopped in a vertical mixer (Valmetal V-Mix 400; Saint-Germain-de-Grantham, QC, Canada) and mixed with concentrate for approximately $20 \mathrm{~min}$. The daily TMR batch was placed into 121-L capacity trash cans (Rubbermaid Commercial Products, Saratoga Springs, NY), weighed on a portable digital ground scale (Rubbermaid Pelouze Digital Receiving Scale) with 0.1-kg readability, and delivered to the cows after each milking. Cows were fed twice daily, at approximately 0630 and $1600 \mathrm{~h}$, and had free access to water throughout the experiment. The amount of feed offered to the cows was adjusted daily to yield refusals equal to approximately 5 to $10 \%$ of intake. Refusals were collected daily before the morning feeding and weighed in the same manner reported for the TMR. Feed intake was recorded by subtracting the amount of TMR offered daily from the amount of refusals. The Calan doors system (American Calan Inc.) was used to individualize the dietary treatments offered to the cows. Each ANOD dose $(57,113$, or $170 \mathrm{~g})$ was mixed daily by hand with $450 \mathrm{~g}$ (as fed basis) of the same concentrate used in the TMR and offered to the cows in small rubber tubs immediately before the morning feeding to ensure complete consumption of the supplement. Cows assigned to the control diet also received $450 \mathrm{~g}$ of concentrate daily to maintain a similar amount of concentrate feeding across treatments. Body weights were recorded at the same time for 3 consecutive days at the beginning of the experiment as well as during the last $3 \mathrm{~d}$ of each period to determine $\mathrm{BW}$ and $\mathrm{BW}$ change.

Samples of TMR, baleage, concentrate, and refusals (composited by diet) were collected daily during 
the collection periods. A sample of ANOD was taken every time a new bag was opened and then composited by period. All feed samples were dried in a forced-air oven $\left(55^{\circ} \mathrm{C}, 48 \mathrm{~h}\right)$, ground to pass through a $1-\mathrm{mm}$ screen (Wiley mill; Arthur H. Thomas, Philadelphia, PA), and shipped to a commercial laboratory (Dairy One Cooperative Inc., Ithaca, NY) for analyses. The following methods were used: DM (method 930.15; AOAC International, 2006), total N (method 990.03; AOAC International, 2006), NDF (method 6; Ankom Technology, Fairport, NY; solutions as in Van Soest et al., 1991), ADF [method 5; Ankom Technology; solutions as in method 973.18 (AOAC International, 1998)], crude fat (method 2003.05; AOAC International, 2006), and ash (method 942.05; AOAC International, 2006). Individual minerals ( $\mathrm{Ca}, \mathrm{P}, \mathrm{Mg}, \mathrm{K}, \mathrm{Na}, \mathrm{Fe}, \mathrm{Zn}, \mathrm{Cu}, \mathrm{Mn}$, Mo, S, and Se) were analyzed (Dairy One Cooperative Inc.) in feed samples using a Thermo IRIS Advantage HX or ICAP 6300 intrepid inductively coupled plasma radial spectrometer after microwave digestion (CEM application note for acid digestion; CEM, Matthews, $\mathrm{NC}$ ). The $\mathrm{Cl}$ ion was analyzed (Dairy One Cooperative Inc.) in feeds using a Brinkmann Metrohm 716 Titrino Titration Unit with a silver electrode (Metrohm application bulletin no. 130; Metrohm Ltd., Herisau, Switzerland). Feed I was analyzed by inductively coupled plasma mass spectrometry at Dartmouth College Trace Metal Analysis Laboratory (Hanover, NH). The TMR and ANOD samples were also analyzed (Dairy One Cooperative Inc.) for soluble protein (Licitra et al., 1996), NDIN (LecoTruMac N Macro Determinator on NDF residue; Leco Corporation, St. Joseph, MI), ADIN (LecoTruMac N Macro Determinator on ADF residue; Leco Corporation), lignin [Ankom Technology method 9; solutions as in method 973.18 (AOAC International, 1998)], starch (YSI 2700 SELECT Biochemistry Analyzer; application note no. 319; YSI Inc. Life Sciences, Yellow Springs, OH), and ethanol-soluble carbohydrates (Hall et al., 1999). In addition, TMR and ANOD samples were shipped to Agri-King Analab (Fulton, IL) for acid-insoluble ash analysis (combustion of $\mathrm{ADF}$ residue in a muffle furnace at $500^{\circ} \mathrm{C}$ overnight) and to Pennsylvania State University (Kevin Harvatine Laboratory; University Park, PA) for individual FA analysis by GLC after direct methylation (Sukhija and Palmquist, 1988). Samples of ANOD were further analyzed for individual AA [method 982.30 (AOAC International, 2006); University of Missouri Experiment Station Chemical Laboratories, Columbia], vitamin B (Christiane Girard Laboratory; Dairy and Swine Research and Development Centre, Sherbrooke, QC, Canada) by HPLC (Santschi et al., 2005), and Cr (Agr-King Analab), As, Co, and Se (Dartmouth College Trace Metal Analysis Laboratory) by inductively coupled plasma optical emission spectrometry. Refusals were analyzed for DM, ash, NDF, ADF, and $\mathrm{N}$ according to methods and procedures used for the feed samples outlined previously.

\section{Milk Sampling and Analyses}

Cows were milked twice daily, at 0500 and $1530 \mathrm{~h}$, with milk yield recorded at each milking throughout the experiment. Milk samples were collected for 4 consecutive milkings (d 20 and 21) in each sampling period, preserved in tubes containing 2-bromo-2-nitropropan-1,3 diol, pooled by cow according to morning and evening milk weights, and refrigerated at $4^{\circ} \mathrm{C}$ until shipped to Dairy One Cooperative Inc. for determination of fat, protein, lactose, and MUN by mid-infrared reflectance spectroscopy. Milk samples without preservative were collected concurrently, pooled, and stored at -80 and $-20^{\circ} \mathrm{C}$ until analyzed for milk FA and I, respectively. It is important to note that only the squares 2 and 3 of multiparous cows $(n=8)$ were used for milk FA analyses. Milk samples for FA analyses were extracted, methylated, and analyzed at the University of Vermont (Burlington, VT) by GLC as previously described (Kraft et al., 2003). Milk I analyses were conducted in milk samples at the Michigan State University Diagnostic Center for Population and Animal Health (Lansing, MI) according to the method of Wahlen et al. (2005) using inductively coupled plasma mass spectrometry (Agilent 7500 series; Agilent Technologies Inc.).

\section{Blood Sampling and Analyses}

Blood samples were taken once a day for 2 consecutive days (d 20 and 21) at 1200 and $1700 \mathrm{~h}$ from the coccygeal vein into Vacutainer tubes (Becton Dickinson, Franklin Lakes, NJ), and composited by cow on a volume basis. Vacutainer tubes containing EDTA were used for plasma NEFA and urea N (PUN) analyses, whereas Vacutainer tubes without anticoagulant were used for serum cortisol, $\mathrm{T}_{3}$, and $\mathrm{T}_{4}$. After blood collection, tubes were kept on ice and immediately transported to the laboratory for processing. All blood samples were centrifuged $(3,300 \times g)$ for $20 \mathrm{~min}$ at $5^{\circ} \mathrm{C}$ using an Eppendorf Centrifuge model 5810 (Eppendorf, Hamburg, Germany) within $2 \mathrm{~h}$ of collection. After centrifugation, plasma and serum samples were stored at -20 and $-80^{\circ} \mathrm{C}$, respectively, until analyses. Commercially available kits were used to analyze serum concentrations of $\mathrm{T}_{3}$ (RIA; catalog no. TKT3; Siemens Medical Solutions Diagnostics, Los Angeles, CA) and $\mathrm{T}_{4}$ (RIA; catalog no. TKT4; Siemens Medical Solutions Diagnostics) at Kansas State University (Manhattan, $\mathrm{KS}$ ). Commercial kits were also used to analyze the se- 
rum concentration of cortisol (competitive ELISA, immobilized antigen; catalog no. RCAN-C-270R; BioVendor LLC, Asheville, NC) and the plasma concentration of NEFA [enzymatic colorimetric assay; product name HR series NEFA-HR(2); Wako Diagnostics, Richmond, VA]. Concentration of PUN was analyzed colorimetrically using the diacetyl-monoxime method.

\section{Feces and Urine Sampling and Analyses}

Fecal grab samples were collected once daily for 3 consecutive days (d 19 to 21 ) at 0500, 1200, and 1500 $\mathrm{h}$ by stimulating defecation or collected directly from the rectum. Samples were pooled by cow based on fresh weight (about $200 \mathrm{~g} /$ sampling) over $3 \mathrm{~d}$ to obtain a single composite and stored at $-20^{\circ} \mathrm{C}$ in plastic bags. At the end of each sampling week, composited fecal samples were thawed and placed in aluminum trays in a forced-air oven at $55^{\circ} \mathrm{C}$ until completely dried (approximately $72 \mathrm{~h}$ ). Dried samples were ground to pass through a 1-mm screen (Willey mill) and analyzed for analytical DM, ash, total N, NDF, ADF, and acidinsoluble ash as described previously. Acid-insoluble ash was used as an internal marker to estimate fecal output of DM (Van Keulen and Young, 1977; Cochran et al., 1986).

Spot urine samples were taken once daily for 3 consecutive days (d 19 to 21 ) concurrently with the fecal samples by stimulation of the pudendal nerve massaging the area below the vulva. Immediately following each sampling, urine samples were combined with 800 $\mu \mathrm{L}$ of $6 \mathrm{~N} \mathrm{HCl}$, pooled by cow on a volume basis, and stored in 3 separate $50-\mathrm{mL}$ centrifuge tubes at $-20^{\circ} \mathrm{C}$ until analyses. After thawing at room temperature, urinary samples were analyzed colorimetrically for creatinine (assay kit no. 500701; Cayman Chemical Co., Ann Arbor, MI), allantoin (Chen et al., 1992), uric acid (assay kit no. 1045-225; Stanbio Laboratory, Boerne, TX), urea (diacetyl-monoxime method), and total N (micro-Kjeldahl; AOAC, 1990; Dairy One Cooperative Inc.). Daily urinary volume and excretion of total $\mathrm{N}$ were estimated from urinary creatinine concentration assuming a constant creatinine excretion rate of $29 \mathrm{mg} /$ $\mathrm{kg}$ of BW (Valadares et al., 1999). Urinary excretion of purine derivatives (PD; allantoin plus uric acid) was calculated based on the creatinine-to-PD ratio (Chizzotti et al., 2008) assuming a constant creatinine excretion rate of $29 \mathrm{mg} / \mathrm{kg}$ of BW (Valadares et al., 1999).

\section{Statistical Analyses}

Data were analyzed using the MIXED procedure of SAS (SAS version 9.3; SAS Inst. Inc., Cary, NC) ac- cording to a replicated $4 \times 4$ Latin square design. The following model was fitted for all variables:

$$
\mathrm{Y}_{\mathrm{ijkl}}=\mu+\mathrm{S}_{\mathrm{i}}+\mathrm{P}_{\mathrm{j}}+\mathrm{C}_{\mathrm{k}(\mathrm{i})}+\mathrm{T}_{\mathrm{l}}+\mathrm{S} \times \mathrm{T}_{\mathrm{il}}+\mathrm{E}_{\mathrm{ijkl}},
$$

where $\mathrm{Y}_{\mathrm{ijkl}}=$ dependent variable, $\mu=$ overall mean, $\mathrm{S}_{\mathrm{i}}$ = fixed effect of ith square, $\mathrm{P}_{\mathrm{j}}=$ fixed effect of jth period, $\mathrm{C}_{\mathrm{k}(\mathrm{i})}=$ random effect of kth cow within ith square, $\mathrm{T}_{1}=$ fixed effect of lth treatment, $\mathrm{S} \times \mathrm{T}_{\mathrm{il}}=$ interaction between ith square and lth treatment, and $\mathrm{E}_{\mathrm{ijkl}}=$ error term $\sim N\left(0, \sigma_{e}^{2}\right)$. Orthogonal polynomials were used to test responses (linear, quadratic, cubic) from incremental dietary levels of ANOD. All reported values are LSM and SEM. Significance was declared at $P \leq 0.05$ and trends at $0.05<P \leq 0.10$. Cubic effects are not reported in tables but are presented in the text when $P$ $\leq 0.10$. The interaction and cubic terms were removed from the final model when $P \geq 0.25$.

The dietary levels of ANOD were used with the MIXED procedure of SAS (SAS version 9.3) in a regression model that included square, linear, and quadratic terms to obtain the intercept and regression coefficients for some variables reported herein (i.e., urinary excretions of PD and apparent total-tract digestibility of $\mathrm{ADF})$. These equations were then solved for the dose of dietary ANOD that resulted in maximal response of the analyzed variables to ANOD supplementation as follows: [-linear coefficient $\div(2 \times$ quadratic coefficient $)$ ].

\section{RESULTS}

\section{Feeds Nutrient Composition}

Overall, ANOD showed high concentrations of NDF, $\mathrm{ADF}$, and ash, low to moderate concentrations of $\mathrm{CP}$, ethanol-soluble carbohydrates, starch, NSC, and vitamins B, and a low concentration of crude fat (Table 1). Compared with the concentrate and baleage, ANOD showed the lowest concentrations of $\mathrm{P}, \mathrm{Zn}, \mathrm{Cu}, \mathrm{Mn}$, and $\mathrm{Mo}$, the highest concentrations of $\mathrm{Ca}, \mathrm{K}, \mathrm{Na}, \mathrm{S}, \mathrm{Cl}$, and $\mathrm{I}$, and intermediate concentrations of $\mathrm{Mg}$ and $\mathrm{Fe}$ (Table 1). The cis-9 18:1 was the FA with the highest concentration $(5.6 \mathrm{~g} / \mathrm{kg}$ of DM) in the ANOD source used herein (Table 2). The proportions (\% of CP) of Lys, Met, and His in the ANOD source averaged, respectively, $3.2,1.2$, and $1.1 \%$ (Table 2 ).

\section{Animal Performance, Milk Composition, and Blood Metabolites}

Increasing dietary amounts of ANOD did not affect DMI and milk yield, which averaged 17.8 and $16.2 \mathrm{~kg} / \mathrm{d}$, respectively (Table 3 ). It is important to note, however, 
Table 1. Nutritional composition (\% of DM, unless otherwise noted) of $\mathrm{ANOD}^{1}$, TMR, concentrate, and baleage fed to early lactation dairy cows

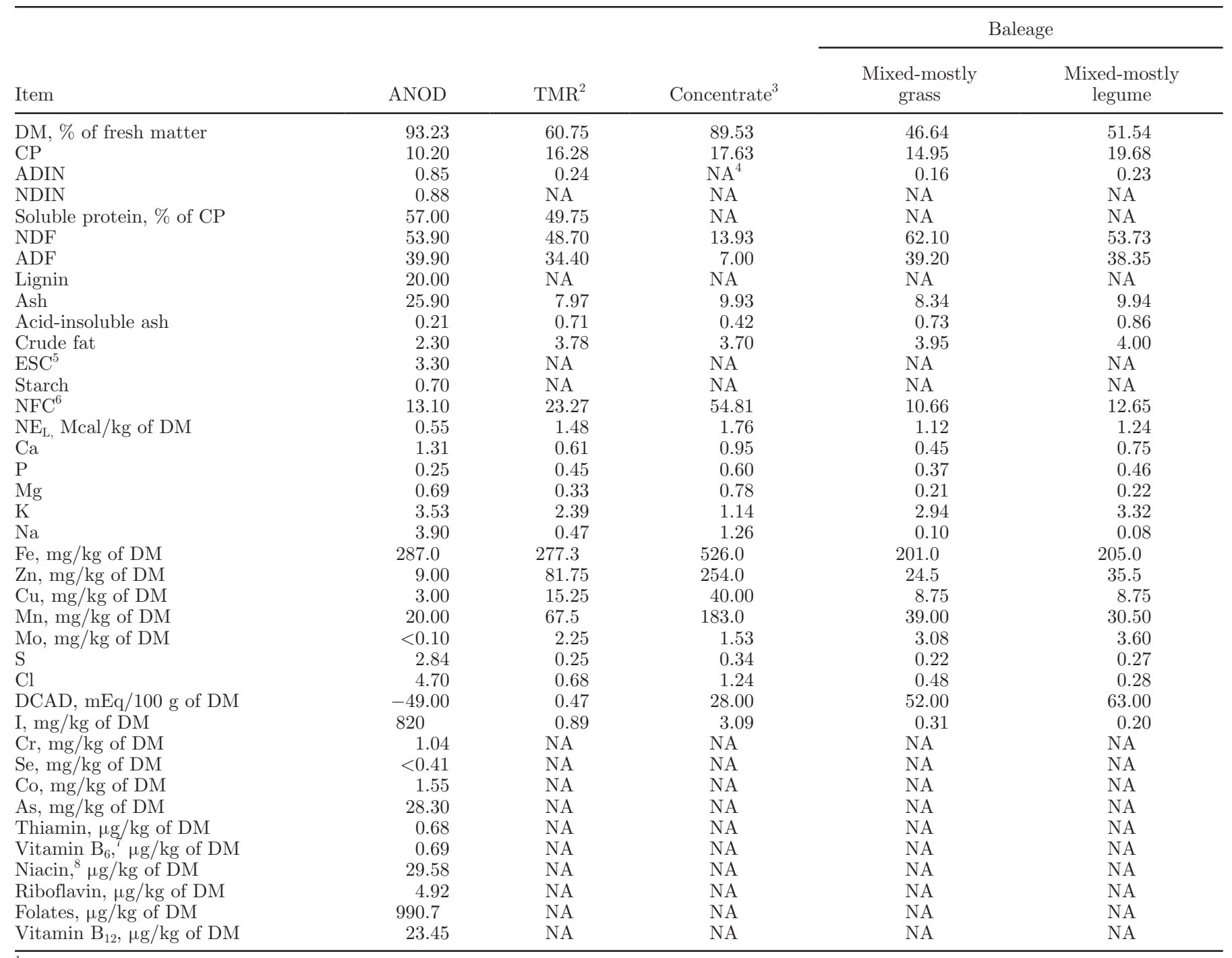

${ }^{1} \mathrm{ANOD}=$ Ascophyllum nodosum meal.

${ }^{2}$ The TMR contained (DM basis): $31.8 \%$ mixed-mostly grass baleage, $32.4 \%$ mixed-mostly legume baleage, and $35.8 \%$ concentrate.

${ }^{3}$ The concentrate contained (as-fed basis): $11.3 \%$ organic soybean meal, $46.7 \%$ organic corn meal, $22.0 \%$ organic barley, $5.2 \%$ organic wheat middlings, $8.0 \%$ organic roasted soybean, 0.82\% dicalcium phosphate (DIKAL 21; Amax Phosphate Inc., Greenwich, CT; $19 \%$ Ca and 21\% P), $1.10 \%$ limestone, $1.25 \%$ sodium bicarbonate, $1.50 \%$ salt, $0.44 \%$ potassium sulfate, $0.72 \%$ magnesium oxide, $0.41 \%$ Se, $0.29 \%$ A-D-E vitamins premix (Cooperative Feed Dealers Inc., Conklin, NY), and $0.34 \%$ standard minerals premix (Cooperative Feed Dealers Inc.). The vitamin and mineral premixes provided (guaranteed analysis): $6,062,721 \mathrm{IU} / \mathrm{kg}$ of vitamin A, 1,653,450 IU $/ \mathrm{kg}$ of vitamin D, 25,353 IU/ $\mathrm{kg}$ of vitamin E, 30\% of Ca, $790 \mathrm{mg} / \mathrm{kg}$ of I, $675 \mathrm{mg} / \mathrm{kg}$ of Co, $6.0 \mathrm{~g} / \mathrm{kg}$ of $\mathrm{Cu}, 4.0 \%$ of $\mathrm{Zn}$, and $2.5 \%$ of $\mathrm{Mn}$.

${ }^{4} \mathrm{NA}=$ not analyzed.

${ }^{5} \mathrm{ESC}=$ ethanol-soluble carbohydrates.

${ }^{6}$ Calculated as $100-[(\% \mathrm{CP}-\% \mathrm{NDICP})+\% \mathrm{NDF}+\%$ crude fat $+\%$ ash $]$ for ANOD and as $100-(\% \mathrm{CP}+\% \mathrm{NDF}+\%$ crude fat $+\%$ ash) for TMR, concentrate, and baleage.

${ }^{7}$ Vitamin $\mathrm{B}_{6}=$ pyridoxamine + pyridoxal + pyridoxine.

${ }^{8}$ Niacin $=$ nicotinic acid + nicotinamide.

that DMI tended $(P=0.09)$ to respond quadratically with increasing ANOD supplementation. Similarly, concentration and yield of milk components (i.e., fat, protein, lactose, SNF, TS, and MUN) were not affected by treatment (Table 3). As a result, $4 \%$ FCM and ECM did not differ significantly across treatments, averaging 18.2 and $21.0 \mathrm{~kg} / \mathrm{d}$, respectively (Table 3). Feed efficiency expressed as milk yield/DMI, $4 \%$ FCM/DMI, or ECM/DMI were not affected by increasing dietary levels of ANOD and averaged $0.91,1.0$, and $1.3 \mathrm{~kg} /$ 
Table 2. Fatty acid composition of $\mathrm{ANOD}^{1,2}$ and $\mathrm{TMR}$, and $\mathrm{AA}$ composition of ANOD fed to early lactation dairy cows

\begin{tabular}{|c|c|c|}
\hline $\mathrm{FA}, \mathrm{g} / \mathrm{kg}$ of $\mathrm{DM}$ & ANOD & TMR \\
\hline 14:0 & 2.18 & 0.10 \\
\hline $16: 0$ & 2.73 & 4.32 \\
\hline $16: 1$ & 0.27 & 0.05 \\
\hline $17: 0$ & $\mathrm{ND}^{3}$ & 0.05 \\
\hline 18:0 & 0.11 & 0.66 \\
\hline cis-9 18:1 & 5.59 & 2.81 \\
\hline cis-11 18:1 & 0.05 & 0.18 \\
\hline cis-9, cis-12 18:2 & 1.48 & 7.65 \\
\hline cis-6,cis-9,cis-12 18:3 & 0.05 & 0.004 \\
\hline cis-9,cis-12,cis-15 18:3 & 0.74 & 5.44 \\
\hline $20: 0$ & 0.01 & 0.20 \\
\hline cis-13 20:1 & ND & 0.06 \\
\hline cis-11,cis-14 20:2 & 0.30 & 0.02 \\
\hline cis- 8, cis-11,cis-14 20:3 & 0.14 & ND \\
\hline $\mathrm{C} 22: 0$ & 0.31 & 0.23 \\
\hline 24:0 & 0.95 & 0.11 \\
\hline cis-15 24:1 & ND & 0.12 \\
\hline
\end{tabular}

${ }^{1} \mathrm{ANOD}=$ Ascophyllum nodosum meal.

${ }^{2} \mathrm{AA}$ composition (\% of CP) of ANOD: 2.63 (Arg), 1.09 (His), 2.35 (Ile), 3.80 (Leu), 3.17 (Lys), 1.18 (Met), 2.54 (Phe), 2.80 (Thr), 0.45 (Trp), 3.17 (Val), 4.08 (Ala), 7.33 (Asp), 1.63 (Cys), 16.02 (Glu), 3.08 (Gly), 0.36 (Orn), 1.90 (Pro), 2.35 (Ser), 0.54 (Tau), and 1.18 (Tyr).

${ }^{3} \mathrm{ND}=$ not detected. $\mathrm{kg}$, respectively (Table 3). Body weight change (mean $=-0.36 \mathrm{~kg} / \mathrm{d}$ ) was not affected by feeding cows incremental amounts of ANOD (Table 3). Concentration of PUN followed that of MUN and did not differ across treatments (Table 3). However, plasma concentration of NEFA was reduced linearly $(P=0.05)$ from 164 to $132 \mathrm{mEq} / \mathrm{L}$ when cows were fed increasing amounts of ANOD (Table 3). In addition, serum concentration of cortisol tended $(P=0.08)$ to decrease linearly with increasing ANOD supplementation (Table 3).

Iodine intake derived from ANOD increased linearly $(P<0.001)$ in response to incremental ANOD supplementation, whereas I intake from TMR tended $(P=0.10)$ to increase linearly (Table 4$)$. As a result, total I intake (ANOD plus TMR) increased linearly $(P<0.001)$ when cows were fed increasing amounts of ANOD (Table 4). Concentration and yield of milk I increased linearly $(P<0.001)$ with increasing ANOD supplementation (Table 4). Serum concentrations of $T_{3}$ and $\mathrm{T}_{4}$ were not affected by treatment and averaged 1.1 and $48.4 \mathrm{ng} / \mathrm{mL}$, respectively (Table 4 ).

With the exception of milk iso 14:0 $(P=0.05$; Table 5), 15:0 ( $P=0.03$; Table 5), trans-4 14:1 $(P=0.05$; data not shown), cis-11 18:1 ( $P=0.04$; data not shown), cis-11 20:1 ( $P=0.04$; data not shown), and cis-7,cis-

Table 3. Least squares means for DMI, milk yield, concentrations and yields of milk components, feed efficiency, and plasma concentrations of urea N (PUN) and NEFA in early lactation dairy cows fed incremental amounts of ANOD ${ }^{1}$

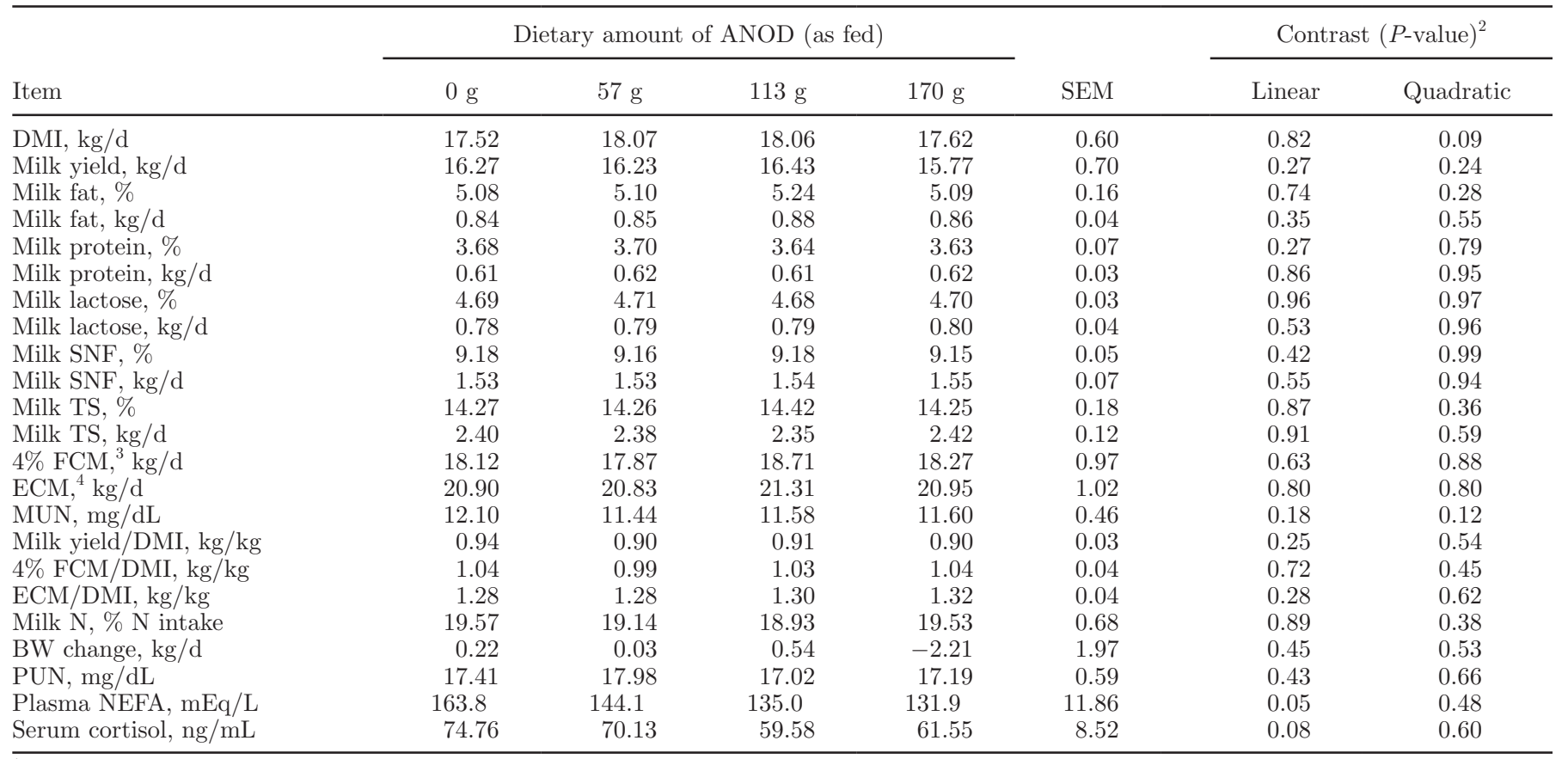

${ }^{1}$ ANOD $=$ Ascophyllum nodosum meal.

${ }^{2}$ Probability of linear and quadratic effects for incremental dietary amounts of ANOD; significance was declared at $P \leq 0.05$ and trends at 0.05 $<P \leq 0.10$.

${ }^{3} 4 \% \overline{\mathrm{FCM}}=[0.40 \times$ milk yield $(\mathrm{kg} / \mathrm{d})]+[15 \times$ milk fat yield $(\mathrm{kg} / \mathrm{d})]($ Gaines and Davidson, 1923).

${ }^{4} \mathrm{ECM}=[0.327 \times$ milk yield $(\mathrm{kg} / \mathrm{d})]+[12.95 \times$ fat yield $(\mathrm{kg} / \mathrm{d})]+[7.2 \times$ protein yield $(\mathrm{kg} / \mathrm{d})]($ Orth, 1992) 
Table 4. Least squares means for I intake, concentration and yield of milk $\mathrm{I}$, and serum concentrations of triiodothyronine $\left(\mathrm{T}_{3}\right)$ and thyroxine $\left(\mathrm{T}_{4}\right)$ in early lactation dairy cows fed incremental amounts of ANOD ${ }^{1}$

\begin{tabular}{|c|c|c|c|c|c|c|c|}
\hline \multirow[b]{2}{*}{ Item } & \multicolumn{4}{|c|}{ Dietary amount of ANOD (as fed) } & \multirow[b]{2}{*}{ SEM } & \multicolumn{2}{|c|}{ Contrast $(P \text {-value })^{2}$} \\
\hline & $0 \mathrm{~g}$ & $57 \mathrm{~g}$ & $113 \mathrm{~g}$ & $170 \mathrm{~g}$ & & Linear & Quadratic \\
\hline TMR I intake, ${ }^{3} \mathrm{mg} / \mathrm{d}$ & 16.64 & 17.26 & 17.26 & 17.04 & 0.54 & 0.35 & 0.15 \\
\hline Total I intake, mg/d & 16.64 & 59.97 & 103.4 & 146.7 & 0.54 & $<0.001$ & 0.90 \\
\hline Milk I, $\mu \mathrm{g} / \mathrm{L}$ & 177.6 & 602.3 & $1,014.8$ & $1,369.9$ & 69.91 & $<0.001$ & 0.48 \\
\hline Milk I, mg/d & 2.82 & 9.33 & 16.11 & 20.58 & 0.86 & $<0.001$ & 0.12 \\
\hline
\end{tabular}

${ }^{1} \mathrm{ANOD}=$ Ascophyllum nodosum meal.

${ }^{2}$ Probability of linear and quadratic effects for incremental dietary amounts of ANOD; significance was declared at $P \leq 0.05$ and trends at 0.05 $<P \leq 0.10$.

${ }^{3}$ Calculated based on TMR I intake plus I provided by the daily dose of the concentrate (450 $\mathrm{g}$ as fed) used to deliver ANOD to cows.

10,cis-13,cis-16 22:4 ( $P=0.05$; data not shown), which responded quadratically when expressed as a proportion of total milk FA, no additional quadratic or linear effects were observed for milk FA in cows fed increasing amounts of ANOD. The milk proportion of 13:0 $(P=$ $0.10)$ as well as the sum of odd- and branched-chain FA $(P=0.06)$ tended to respond quadratically with increasing ANOD supplementation (Table 5). The milk proportions of iso 13:0 $(P=0.03$; Table 5$)$, cis-8 16:1 $(P=0.05$; data not shown $)$, iso $18: 0(P=0.02$; Table 5), cis-11,cis-14,cis-17 20:3 ( $P=0.04$; data not shown), and cis-4,cis-7,cis-10,cis-13,cis-16,cis-19 22:6 ( $P=0.04$; data not shown) responded cubically when diets were supplemented with incremental levels of ANOD (data not shown).

\section{Nitrogen Utilization and Apparent Digestibility of Nutrients}

Urinary concentrations of creatinine $($ mean $=3.4$ $\mathrm{m} M)$ and $\mathrm{PD}$ (mean $=6.4 \mathrm{~m} M$ ) were not affected by incremental dietary levels of ANOD (Table 6). The quadratic maximum for the urinary excretion of $\mathrm{PD}$ was $44 \mathrm{~g} / \mathrm{d}$, which was determined using the following regression equation parameters (coefficient $\pm \mathrm{SE}$ ): $1.75 \pm 0.99$ (linear coefficient) and $-0.0199 \pm 0.0157$ (quadratic coefficient). Whereas the urinary excretion of uric acid did not change across treatments (mean $=14.2 \mathrm{mmol} / \mathrm{d})$, urinary excretions of allantoin $(P=$ $0.01)$ and $\mathrm{PD}(P=0.02)$ responded quadratically to increasing supplementation of ANOD (Table 6). Urinary $\mathrm{N}$ excretion, expressed as grams per day, responded quadratically $(P=0.03)$ when cows were supplemented with increasing amounts of ANOD (Table 6). However, only a quadratic trend $(P=0.10)$ was observed when urinary $\mathrm{N}$ excretion was corrected for $\mathrm{N}$ intake (Table $6)$. Cubic effects were also observed for urinary $\mathrm{N}$ excretion, expressed as grams per day $(P=0.02)$ or as a percentage of $\mathrm{N}$ intake $(P=0.01)$, with increasing amounts of ANOD. Excretion of urinary urea $\mathrm{N}$ expressed as grams per day, percentage of urinary $\mathrm{N}$ excretion, or as a percentage of $\mathrm{N}$ intake was not affected by incremental amounts of ANOD and averaged $137 \mathrm{~g} / \mathrm{d}, 83.1 \%$, and $29.5 \%$, respectively (Table 6).

Intakes of OM (mean $=16.4 \mathrm{~kg} / \mathrm{d}$; data not shown $)$, $\mathrm{NDF}$ (mean $=8.7 \mathrm{~kg} / \mathrm{d}$; data not shown), ADF (mean $=6.0 \mathrm{~kg} / \mathrm{d}$; data not shown), and $\mathrm{N}($ mean $=474 \mathrm{~g} / \mathrm{d}$; Table 6) were not affected by treatment. Apparent total-tract digestibilities of $\mathrm{OM}(P=0.08)$ and NDF $(P=0.10)$ tended to respond quadratically, whereas digestibility of ADF responded quadratically $(P=0.04)$ as a result of increasing dietary levels of ANOD (Table 6). The quadratic maximum for the apparent total-tract digestibility of ADF was $70 \mathrm{~g} / \mathrm{d}$, which was determined using the following regression equation parameters (coefficient \pm SE): $0.0578 \pm 0.0358$ (linear coefficient) and $-0.00041 \pm 0.00020$ (quadratic coefficient). A trend $(P$ $=0.09$ ) for linear reduction in the apparent total-tract digestibility of $\mathrm{N}$ was observed in cows supplemented with increasing levels of ANOD (Table 6).

\section{DISCUSSION}

The concentration of I in the ANOD source fed herein was comparable to that of a similar ANOD supplement (i.e., Tasco-14) reported elsewhere $(<1,000 \mathrm{mg} / \mathrm{kg}$ of DM; Allen et al., 2001a), but much higher than the I contents detected for the baleage and concentrate used in the TMR. This is not surprising because of the high concentration of I in seawater and the capacity of marine plants to readily uptake I (Underwood and Suttle, 1999). Based on NRC (2001), cows in the present study should have consumed $6.7 \mathrm{mg}$ of I daily to meet lactation requirements. Iodine intake from ANOD resulted in 43,86 , and $130 \mathrm{mg} / \mathrm{d}$, thus exceeding requirements by $6-, 13-$, and 19-fold, respectively. Current US Food 
Table 5. Least squares means for odd- and branched-chain FA (OBCFA), SFA, and unsaturated FA in early lactation dairy cows fed incremental amounts of $\mathrm{ANOD}^{1}$

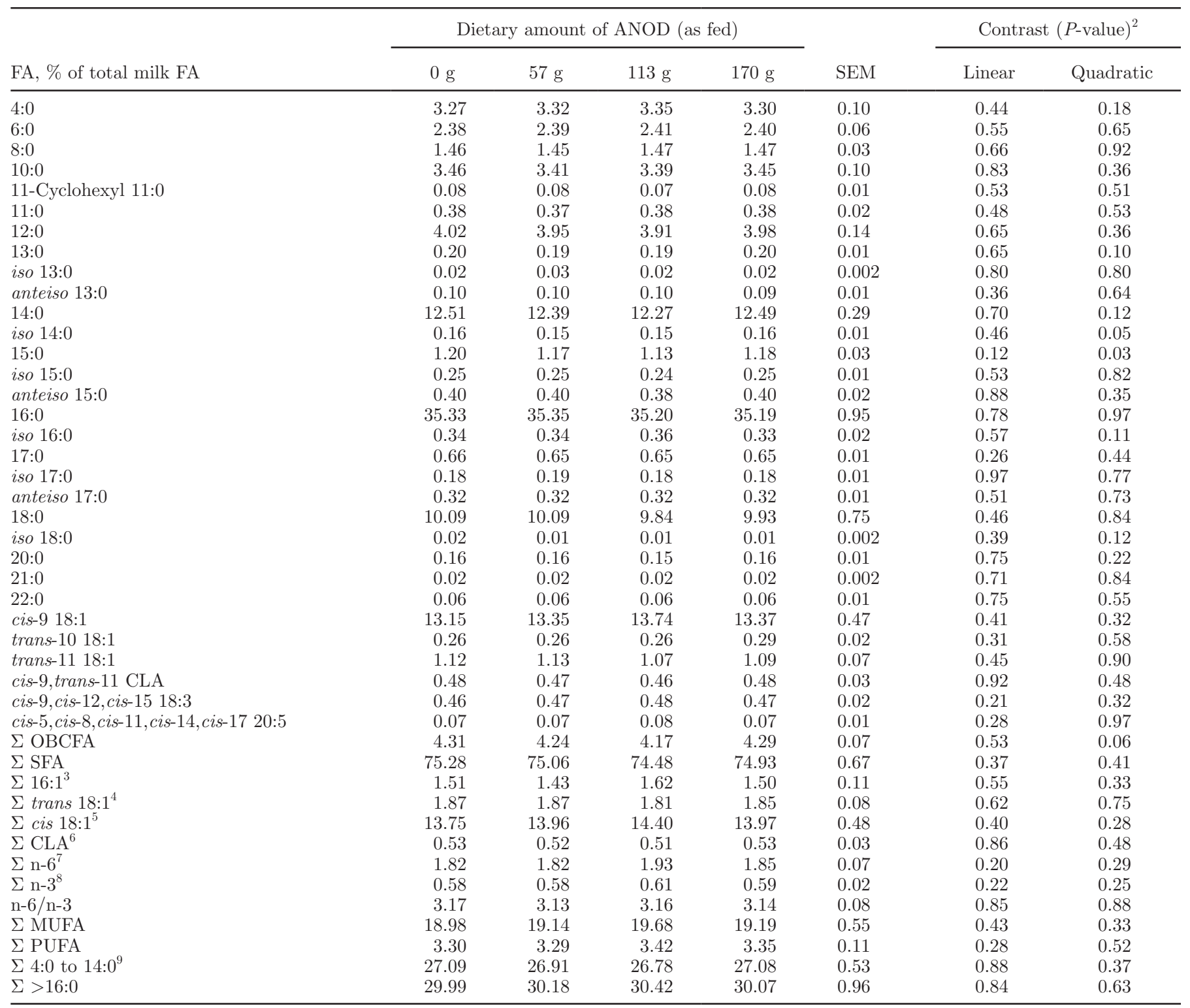

${ }^{1} \mathrm{ANOD}=$ Ascophyllum nodosum meal.

${ }^{2}$ Probability of linear and quadratic effects for incremental dietary amounts of ANOD; significance was declared at $P \leq 0.05$ and trends at 0.05 $<P \leq 0.10$.

${ }^{3}$ cis-7 16:1 + cis-8 16:1 + cis-9 16:1 + trans-9 16:1 + cis-10/trans-13 16:1 + cis-11 16:1 + 16:1 isomer.

${ }^{4}$ trans-4 18:1 + trans-5 18:1 + trans-6-8 18:1 + trans-9 18:1 + trans-10 18:1 + trans-11 18:1 + trans-12 18:1.

${ }^{5}$ cis-9 18:1 + cis-11 18:1 + cis-12 18:1 + cis-13 18:1 + cis-15 18:1 + cis-16 18:1.

${ }^{6}$ trans-11,trans- $13+$ trans- 7, trans- $9 /$ trans- 10, trans $-12+$ cis- 9, cis- $11+$ cis- 9, trans $-11+$ trans -9, cis- 11.

${ }^{7}$ cis-9,cis-12 18:2 + cis-6,cis-9,cis-12 18:3 + cis-11,cis-14 20:2 + cis-5,cis-8,cis-11 20:3 + cis-5,cis-8,cis-11,cis-14 20:4 + cis-7,cis-10,cis-13,cis-16 $22: 4$.

${ }^{8}$ cis-9,cis-12,cis-15 18:3 + cis-11,cis-14,cis-17 20:3 + cis-5,cis-8,cis-11,cis-14,cis-17 20:5 + cis-7,cis-10,cis-13,cis-16,cis-19 22:5 + cis-4,cis-7,cis10,cis-13,cis-16,cis-19 22:6.

${ }^{9} 4: 0+6: 0+8: 0+10: 0+12: 0+14: 0$.

and Drug Administration regulations set the maximum limit of I supplementation from ethylenediamine dihydroiodine (commonly known as EDDI) at $10 \mathrm{mg} /$ head per day due to concerns of I adverse effects to human health through milk consumption (NRC, 2001). A similar type of regulation may need to be extended 
Table 6. Least squares means for $\mathrm{N}$ intake, urinary concentration and excretion of purine derivatives (PD; allantoin plus uric acid), urinary excretion of $\mathrm{N}$ and urea $\mathrm{N}$, and apparent total-tract digestibility of nutrients in early lactation dairy cows fed incremental amounts of ANOD ${ }^{1}$

\begin{tabular}{|c|c|c|c|c|c|c|c|}
\hline \multirow[b]{2}{*}{ Item } & \multicolumn{4}{|c|}{ Dietary amount of ANOD (as fed) } & \multirow[b]{2}{*}{ SEM } & \multicolumn{2}{|c|}{ Contrast $(P \text {-value })^{2}$} \\
\hline & $0 \mathrm{~g}$ & $57 \mathrm{~g}$ & $113 \mathrm{~g}$ & $170 \mathrm{~g}$ & & Linear & Quadratic \\
\hline Creatinine, $\mathrm{mmol} / \mathrm{L}$ & 3.41 & 3.21 & 3.32 & 3.47 & 0.16 & 0.59 & 0.16 \\
\hline $\mathrm{PD}, \mathrm{mmol} / \mathrm{L}$ & 6.11 & 6.90 & 6.43 & 6.32 & 0.34 & 0.85 & 0.15 \\
\hline PD:creatinine ratio & 1.85 & 2.20 & 2.00 & 1.86 & 0.14 & 0.70 & 0.03 \\
\hline Allantoin, mmol/d & 221.8 & 271.7 & 241.2 & 221.7 & 18.30 & 0.71 & 0.01 \\
\hline $\mathrm{N}$ excretion, $\mathrm{g} / \mathrm{d}$ & 148.5 & 184.2 & 159.8 & 159.6 & 8.83 & 0.76 & 0.03 \\
\hline $\mathrm{N}$ excretion, $\%$ of $\mathrm{N}$ intake & 31.89 & 39.53 & 34.04 & 35.86 & 1.95 & 0.37 & 0.10 \\
\hline Urea $\mathrm{N}$ excretion, $\mathrm{g} / \mathrm{d}$ & 129.3 & 143.1 & 141.4 & 132.3 & 8.65 & 0.93 & 0.16 \\
\hline Urea $\mathrm{N}$ excretion, $\%$ of urinary $\mathrm{N}$ & 86.11 & 77.80 & 84.97 & 83.52 & 2.62 & 0.94 & 0.16 \\
\hline Urea $\mathrm{N}$ excretion, $\%$ of $\mathrm{N}$ intake & 27.33 & 30.74 & 30.12 & 29.82 & 2.09 & 0.56 & 0.39 \\
\hline OM digestibility, $\%$ of OM intake & 72.30 & 72.86 & 73.63 & 71.44 & 0.86 & 0.60 & 0.08 \\
\hline NDF digestibility, $\%$ of NDF intake & 68.71 & 69.28 & 70.16 & 67.35 & 1.09 & 0.48 & 0.10 \\
\hline
\end{tabular}

${ }^{1} \mathrm{ANOD}=$ Ascophyllum nodosum meal.

${ }^{2}$ Probability of linear and quadratic effects for incremental dietary levels of ANOD; significance was declared at $P \leq 0.05$ and trends at $0.05<$ $P \leq 0.10$.

${ }^{3}$ Calculated based on the PD:creatinine ratio (Chizzotti et al., 2008) assuming a constant creatinine excretion rate of $29 \mathrm{mg} / \mathrm{kg}$ of BW (Valadares et al., 1999).

to $A$. nodosum based-products because of the high concentration of I in milk of cows fed ANOD as discussed in detail later.

Milk yield, 4\% FCM, and ECM, as well as concentrations and yields of milk components, were not affected by incremental dietary levels of ANOD. Pompeu et al. (2011) and Karatzia et al. (2012) observed no effect on yields of milk and milk components in dairy cows supplemented with a range of 56 to 132 or $80 \mathrm{~g} / \mathrm{d}$ of ANOD, respectively. Conversely, Cvetkovic et al. (2004) reported a significant increase in milk production $(+1.7$ $\mathrm{kg} / \mathrm{d}$ ) in dairy cows fed $57 \mathrm{~g} / \mathrm{d}$ of ANOD during the last 5 wk of the experiment. Similarly, Bendary et al. (2013) observed significant increases in milk yield $(+10.5 \%)$ and $4 \% \mathrm{FCM}(+11.9 \%)$ in Friesian cows supplemented with $50 \mathrm{~g} / \mathrm{d}$ of ANOD. A significant interaction between ANOD supplementation (mean $=104 \mathrm{~g} / \mathrm{d}$ ) and dairy breed was observed by Kellogg et al. (2006) with the large-size cows (primarily Holstein) producing more milk $(2.3 \mathrm{~kg} / \mathrm{d})$ when offered ANOD, but no difference was found for their small-size counterparts (primarily Jersey, Milking Shorthorn, and Holstein $\times$ Jersey crossbred). The positive responses in milk production previously reported are possibly explained by ANOD beneficial effects on mitigating heat stress while providing essential macro- and microminerals to dairy cows (Cvetkovic et al., 2004; Kellogg et al., 2006; Bendary et al., 2013). In fact, these 3 studies were conducted during the hot summer months, and the control diet used in the experiment of Bendary et al. (2013) was not balanced for minerals.

Concentration of serum cortisol tended to decrease linearly with increasing amounts of ANOD. Even though cows used herein were not assessed for signs of cold stress, this possibility cannot be ruled out because the mean environmental temperature $\left(0.33^{\circ} \mathrm{C}\right.$; range $=-20.0$ to $17.7^{\circ} \mathrm{C}$ ) during the experiment was below the lower critical temperature threshold for dairy cows (Berman et al., 1985; Kadzere et al., 2002). Cows in the current experiment were housed in a bedded-pack barn with free access to a cement-floor outdoor lot ending in a roof-covered feeding station. Consequently, cows were occasionally exposed to wind, rain, and snow. Allen et al. (2001b) observed increased rectal temperature in feedlot steers that have grazed endophyte-infected tall fescue pasture treated with an A. nodosum extract product (i.e., Tasco-Forage), suggesting modulation of core body temperature through internal themoregulatory mechanisms. Therefore, ANOD may have helped cows cope better with the cold conditions by raising their core body temperature potentially explaining the reduction in serum cortisol. Although the mechanism by which $A$. nodosum-based products alleviate stress is not well understood, it appears that upregulation of antioxidant enzymes is involved (Allen et al., 2001a). Ascophyllum nodosum contains microminerals such as $\mathrm{Cu}, \mathrm{Zn}$, and $\mathrm{Fe}$, which are known to participate in animals' antioxidant responses (Allen et al., 2001a). In ad- 
dition, ANOD also contains vitamins with antioxidant properties including vitamins $\mathrm{A}(\beta$-carotene $=2,560$ $\mathrm{IU} / \mathrm{g}), \mathrm{C}(81.9 \mathrm{mg} / 100 \mathrm{~g})$, and E (10.2 IU/100 g; Eli Chandler, Thorvin, Inc. Operations Manager, personal communication).

Archer et al. (2007), feeding incremental amounts (0, $6.6,13.2$, and $26.4 \mathrm{~g} / \mathrm{d}$ ) of ANOD to lambs, reported a linear reduction in the concentration of plasma cortisol before and after forced walking in hot temperatures and pre- and post-transportation. However, ANOD also suppressed the antibody response (IgG and $\operatorname{IgM}$ ) when animals were challenged with ovoalbumin and the plasma concentration of aldosterone pre-transportation (liner effect), suggesting impairment of the adrenal gland function (Archer et al., 2007). In a subsequent study, Archer et al. (2008) also observed a significant depression in the humoral response (IgG and $\operatorname{IgM}$ ) to ovoalbumin challenge and a tendency to decreased plasma concentration of both cortisol and aldosterone pre-transportation as a result of ANOD supplementation $(30 \mathrm{~g} / \mathrm{d})$. These results reinforce the negative effect of ANOD on the immune system and adrenal gland function.

The linear reduction in plasma concentration of NEFA when cows were supplemented with increasing amounts of ANOD may be explained by serum cortisol. It is well known that the cortisol action mechanism is antagonistic to that of insulin, thus reducing uptake of glucose by peripheral tissues but increasing lipids mobilization from the adipose tissue during periods of stress, which could enhance energy availability to the animal (Munck et al., 1984; Sapolsky et al., 2000).

As a result of the linear increase in I intake, milk concentration and output of I also increased linearly in cows fed incremental amounts of ANOD, which is explained by the presence of sodium iodide symporter in the lactating mammary gland (Cavalieri, 1997; Laurberg et al., 2002). Children 2 to 3 yr old should consume 2 cups (approximately $473 \mathrm{~mL}$ ) of fat-free or low-fat milk and milk products daily in United States as part of a healthy diet (USDA-USDHHS, 2010). This recommended consumption of milk would result in 84 , 285,542 , and $648 \mu \mathrm{g}$ of I intake daily using milk I concentrations from cows fed $0,57,113$, and $170 \mathrm{~g} / \mathrm{d}$ of ANOD, respectively. The tolerable upper intake limit for I consumption by children 1 to $3 \mathrm{yr}$ old is $200 \mu \mathrm{g} / \mathrm{d}$ (IOM, 2001). Therefore, children in this age group consuming 2 cups of milk daily from cows fed 57, 113, and $170 \mathrm{~g} / \mathrm{d}$ of ANOD would be over the tolerable upper intake limit for I by 30,63 , and $69 \%$, respectively. Even though chronic consumption of excess I does not generally represent an important public health concern in the United States (Pearce et al., 2004), it may increase the risk of thyroiditis, hyperthyroidism, hypothyroid- ism, and goiter (Pennington, 1989). Specifically, Zimmerman et al. (2005) concluded that chronically high I intake $\geq 500 \mu \mathrm{g} / \mathrm{d}$ in school-age children increased thyroid size. Moreover, the consequences of prolonged exposure to high intake of I, particularly in children, are not well understood and require further research (Zimmermann et al., 2005). However, it is noteworthy that concentrations of milk iodine, ranging from 602 $(57 \mathrm{~g} / \mathrm{d}$ of ANOD) to $1,370 \mu \mathrm{g} / \mathrm{L}(170 \mathrm{~g} / \mathrm{d}$ of ANOD), are not likely to be found in retail milk available to consumers because of the common practice of pooling milk from different farms by milk processors, thus diluting the I concentration.

Even though quadratic and cubic responses were observed for the proportions of some milk FA in response to ANOD supplementation in the current study, the actual differences between treatments or the actual proportions of these milk FA were very low and likely not biologically important. We are not aware of previous studies that investigated the effect of ANOD on milk FA profile, but Fike et al. (2005) reported reductions in the proportions of muscle total SFA but no effect on total unsaturated FA in lambs supplemented with $A$. nodosum extracts compared with the control treatment.

The observed quadratic effects for the urinary excretion of PD suggest that microbial protein synthesis was maximized at $44 \mathrm{~g} / \mathrm{d}$ of ANOD supplementation. Ascophyllum nodosum contains macro- and microminerals, vitamins, and phlorotannins that may exert stimulatory or inhibitory effects in the ruminal microorganims. Wang et al. (2008) observed linear decrease in gas production in vitro when using mixed forage (i.e., 25:25:50 barley silage:alfalfa hay:grass hay) or barley grain incubated with increasing concentrations $(0,125,250$, or $500 \mu \mathrm{g} / \mathrm{mL}$ ) of phlorotannins extracted from $A$. nodosum. However, in the presence of polyethylene glycol, a compound that selectively inactivates tannins, gas production was linearly increased in vitro (Wang et al., 2008). This suggests that, after phlorotannins-polyethylene glycol complexes were formed, unidentified compounds present in the $A$. nodosum crude extracts were used as substrates for fermentation, or that these compounds stimulated fermentation of other constituents of the diet (Wang et al., 2008). Phlorotannins have been shown to exhibit antimicrobial activity against ruminal bacteria in vitro (Wang et al., 2008) and pathogenic microorganisms, such as different strains of Escherichia coli O157:H7 (Wang et al., 2009).

Quadratic and cubic effects observed for the urinary excretion of $\mathrm{N}$ with increasing dietary levels of ANOD cannot be explained by $\mathrm{N}$ intake. Previous in vitro (Wang et al., 2008) and in vivo (Bendary et al., 2013) studies reported reductions in the concentration of ruminal $\mathrm{NH}_{3}-\mathrm{N}$ likely in response to reduced proteolysis 
in the rumen caused by phlorotannins originated from A. nodosum. In fact, phlorotannins decreased proteolysis of casein and deamination of AA in vitro (Wang et al., 2008). Reduced ruminal $\mathrm{NH}_{3}-\mathrm{N}$ concentration has been associated with decreased urinary $\mathrm{N}$ excretion in lactating dairy cows fed diets with increasing levels of CP (Colmenero and Broderick, 2006). However, the concentration of ruminal $\mathrm{NH}_{3}-\mathrm{N}$ was not affected in previous studies when lambs were fed poor-quality tall fescue hay supplemented with $A$. nodosum extract products (i.e., Tasco-Forage or Tasco-EX; Fike et al., 2005) or when steers were fed poor-quality switchgrass (Panicum virgatum) hay supplemented with cooked molasses block containing ANOD (Leupp et al., 2005). Therefore, it is difficult to explain the quadratic and cubic effects observed herein for the urinary excretion of $\mathrm{N}$.

Apparent total-tract ADF digestibility was maximized at $70 \mathrm{~g} / \mathrm{d}$ of ANOD supplementation in the current experiment, suggesting that specific ANOD components may have stimulated cellulolytic microorganisms in the rumen in a dose-dependent fashion. In the in vitro study of Wang et al. (2008), increasing levels of phlorotannins extracted from $A$. nodosum led to a linear decrease in the in vitro disappearance of aNDF when a mixed forage source was used as substrate. Conversely, in situ ruminal disappearance of NDF and ADF was not affected in steers fed cooked molasses blocks with or without ANOD (Leupp et al., 2005). Pioneer in vitro work showed that vitamin B (e.g., biotin, vitamin $\mathrm{B}_{6}$, folic acid, riboflavin, thiamin, and vitamin $\mathrm{B}_{12}$ ) and $\rho$-aminobenzoic acid were required by the 3 major ruminal cellulolytic bacteria (i.e., Ruminococcus albus, Ruminococcus flavefaciens, and Fibrobacter succinogenes) for maximal growth and cellulose digestion (Hall et al., 1953; Bentley et al., 1954, 1955; Scott and Dehority, 1965). Thus, vitamin B present in ANOD may have been involved to some extent with the quadratic response observed for ADF digestibility in the current experiment. Overall, our results suggest that at lower doses of ANOD supplementation $(\leq 70$ $\mathrm{g} / \mathrm{d})$ specific compounds present in ANOD appear to stimulate the growth of ruminal cellulolytic bacteria, whereas at a higher doses $(>70 \mathrm{~g} / \mathrm{d})$ the concentration of phlorotannins may reach levels that offset growth promoters.

The linear trend for decreased apparent total-tract digestibility of $\mathrm{N}$ with increasing dietary levels of ANOD may be explained by phlorotannins, which are known to make complex with proteins (Ragan and Glombitza, 1986). Hymes-Fecht et al. (2013) observed decreased apparent total-tract digestibility of $\mathrm{N}$ in lactating dairy cows when comparing silage sources [i.e., alfalfa and red clover (Trifolium pretense) low in condensed tan- nins versus birdsfoot trefoil (Lotus corniculatus L.) silage containing different concentrations of condensed tannins].

\section{CONCLUSIONS}

Overall, animal performance, including DMI, milk yield, and concentrations and yields of milk components (i.e., fat, protein, lactose, SNF, and TS), was not affected by increasing dietary levels of ANOD. However, concentration and output of milk I increased linearly in cows fed incremental amounts of ANOD due to the high concentration of I in the ANOD source fed herein. Because the milk I concentration reached levels that may be toxic to humans, particularly children, ANOD supplementation to dairy cows should be done cautiously. Plasma concentration of NEFA reduced linearly with ANOD supplementation, suggesting reduced mobilization of lipids from the adipose tissue. Both urinary excretion of $\mathrm{PD}$ and the apparent total-tract digestibility of ADF responded quadratically to ANOD supplementation with quadratic maxima at 44 and 70 $\mathrm{g} / \mathrm{d}$, respectively. These results suggest that at lower doses of supplementation $(\leq 70 \mathrm{~g} / \mathrm{d})$ specific compounds present in ANOD appear to stimulate the growth of ruminal cellulolytic bacteria, whereas at a higher doses $(>70 \mathrm{~g} / \mathrm{d})$ the concentration of phlorotannins may reach levels that offset growth promoters. Therefore, further research is needed to better understand the effect of ANOD supplementation on ruminal fermentation and metabolism in lactating dairy cows. Based on the current results, farmers should be cautious about supplementing early lactation cows with ANOD if their primary goal is to improve animal production.

\section{ACKNOWLEDGMENTS}

Partial funding was provided by the New Hampshire Agricultural Experiment Station. This is Scientific Contribution Number 2588. This work was supported by the USDA National Institute of Food and Agriculture (Hatch Multistate NC-1042 Project Number NH00616R; Project Accession Number 1001855).Gratitude is extended to Melissa Rubano (USDA-Agricultural Research Station, Pasture Systems and Watershed Management Research Unit) and Melissa Bainbridge (University of Vermont) for technical assistance, as well as University of New Hampshire undergraduate students Elizabeth Fletcher, Samantha Werner, Gina Soule, Adam Crowther, and Justin Stilwell for support during samples collection. We also thank Christiane Girard (Agriculture and Agri-Food Canada/Dairy and Swine Research and Development Centre; Sherbrooke, QC, Canada) for vitamin B analysis and Thorvin Inc. 
(New Castle, VA) for donating the kelp meal used in the present study. We thank the University of New Hampshire Burley-Demeritt Organic Dairy Research Farm former manager Trent Schrieffer and his staff for animal care and overall research support.

\section{REFERENCES}

Allen, G., K. R. Pond, K. E. Saker, J. P. Fontenot, C. P. Bagley, R. L. Ivy, R. R. Evans, R. E. Schmidt, J. H. Fike, X. Zhang, J. Y. Ayad, C. P. Brown, M. F. Miller, J. L. Montgomery, J. Mahan, D. B. Wester, and C. Melton. 2001a. Tasco: Influence of a brown seaweed on antioxidants in forages and livestock-A review. J. Anim. Sci. 79:E21-E31.

Allen, V. G., K. R. Pond, K. E. Saker, J. P. Fontenot, C. P. Bagley, R. L. Ivy, R. R. Evans, C. P. Brown, M. F. Miller, J. L. Montgomery, T. M. Dettle, and D. B. Wester. 2001b. Tasco-Forage: III. Influence of a seaweed extract on performance, monocyte immune cell response, and carcass characteristics in feedlot-finished steers. J. Anim. Sci. 79:1032-1040.

AOAC. 1990. Official Methods of Analysis. 15th ed. AOAC, Arlington, VA.

AOAC International. 1998. Official Methods of Analysis. 16th ed. AOAC International, Arlington, VA.

AOAC International. 2006. Official Methods of Analyses. 18th ed. AOAC International, Gaithersburg, MD.

Archer, G. S., T. H. Friend, D. Caldwell, K. Ameiss, and P. D. Krawczel. 2007. Effect of the seaweed Ascophyllum nodosum on lambs during forced walking and transport. J. Anim. Sci. 85:225-232.

Archer, G. S., T. H. Friend, D. Caldwell, K. Ameiss, P. D. Krawczel, C. Iacono, H. Keena, and T. Martin. 2008. Impacts of feeding several components of the seaweed Ascophyllum nodosum on transported lambs. Anim. Feed Sci. Technol. 140:258-271.

Bendary, M. M., M. I. Bassiouni, M. F. Ali, H. M. Gaafar, and A. Sh. Shamas. 2013. Effect of premix and seaweed additives on productive performance of lactating Friesian cows. Int. Res. J. Agric. Sci. Soil Sci. 3:174-181.

Bentley, O. G., R. R. Johnson, T. V. Hershberger, J. H. Cline, and A. L. Moxon. 1955. Cellulolytic factor activity of certain shortchain fatty acids for rumen microorganisms in vitro. J. Nutr. 57:389-400.

Bentley, O. G., R. R. Johnson, S. Vanecko, and C. H. Hunt. 1954. Studies on factors needed by rumen microorganisms for cellulose digestion in vitro. J. Anim. Sci. 13:581-593.

Berman, A., Y. M. Folman, M. Kaim, Z. Mamen, D. Herz, A. Wolfenson, and Y. Graber. 1985. Upper critical temperatures and forced ventilation effects for high-yielding dairy cows in a tropical climate. J. Dairy Sci. 68:1488-1495.

Berry, M. H., and K. L. Turk. 1944. The value of kelp meal in rations for dairy cattle. J. Dairy Sci. 27:861-866.

Castro, S. I., R. Berthiaume, A. Robichaud, and P. Lacasse. 2012. Effects of iodine intake and teat-dipping practices on milk I concentrations in dairy cows. J. Dairy Sci. 95:213-220.

Castro, S. I., P. Lacasse, A. Fouquet, F. Beraldin, A. Robichaud, and R. Berthiaume. 2011. Short communication: Feed iodine concentrations on farms with contrasting levels of I in milk. J. Dairy Sci. 94:4684-4689.

Cavalieri, R. R. 1997. Iodine metabolism and thyroid physiology: Current concepts. Thyroid 7:177-181.

Chen, X. B., Y. K. Chen, M. F. Franklin, E. R. Ørskov, and W. J. Shand. 1992. The effect of feed intake and body weight on purine derivative excretion and microbial protein supply in sheep. J. Anim. Sci. 70:1534-1542.

Chizzotti, M. L., S. C. Valadares Filho, R. F. D. Valadares, F. H. M. Chizzotti, and L. O. Tedeschi. 2008. Determination of creatinine excretion and evaluation of spot urine sampling in Holstein cattle. Livest. Sci. 113:218-225.
Cochran, R. C., D. C. Adams, J. D. Wallace, and M. L. Galyean. 1986. Predicting digestibility of different diets with internal markers: Evaluation of four potential markers. J. Anim. Sci. 63:1476-1487.

Colmenero, J. J., and G. A. Broderick. 2006. Effect of dietary crude protein concentration on milk production and nitrogen utilization in lactating dairy cows. J. Dairy Sci. 89:1704-1712.

Cvetkovic, B., M. J. Brouk, and J. E. Shirley. 2004. Impact of dried seaweed meal on heat stressed lactating dairy cattle. Dairy Day (Report of Progress 941). Kansas State University Agricultural Experiment Station and Cooperative Extension Service. Accessed Jul. 13, 2014. http://www.ksre.ksu.edu/historicpublications/ pubs/SRP941.pdf.

Dahl, L., J. A. Opsahl, H. M. Meltzer, and K. Julshamn. 2003. Iodine concentration in Norwegian milk and dairy products. Br. J. Nutr. 90:679-685.

Fike, J. H., V. G. Allen, R. E. Schmidt, X. Zhang, J. P. Fontenot, C. P. Bagley, R. L. Ivy, R. R. Evans, R. W. Coelho, and D. B. Wester. 2001. Tasco-Forage: I. Influence of a seaweed extract on antioxidant activity in tall fescue and in ruminants. J. Anim. Sci. 79:1011-1021.

Fike, J. H., K. E. Saker, S. F. O'Keefe, N. G. Marriott, D. L. Ward, J. P. Fontenot, and H. P. Veit. 2005. Effects of Tasco (a seaweed extract) and heat stress on $\mathrm{N}$ metabolism and meat fatty acids in wether lambs fed hays containing endophyte-infected fescue. Small Rumin. Res. 60:237-245.

Fitzgerald, C., E. Gallagher, D. Tasdemir, and M. Hayes. 2011. Heart health peptides from macroalgae and their potential use in functional foods. J. Agric. Food Chem. 59:6829-6836.

Franke, K., U. Meyer, H. Wagner, and G. Flachowsky. 2009. Influence of various iodine supplementation levels and two different iodine species on the iodine content of the milk of cows fed rapeseed meal or distillers dried grains with solubles as the protein source. J. Dairy Sci. 92:4514-4523.

Gaines, W. L., and F. A. Davidson. 1923. Relation between percentage fat content and yield of milk. Bull. 245. Ill. Agric. Expt. Sta., Urbana, IL.

Hall, G., E. W. Cheng, and W. Burrows. 1953. B-vitamins and other factors stimulatory to cellulose digestion by washed suspensions of rumen microorganisms. J. Anim. Sci. 12:918-919.

Hall, M. B., W. H. Hoover, J. P. Jennings, and T. K. M. Webster. 1999. A method for partitioning neutral detergent soluble carbohydrates. J. Sci. Food Agric. 79:2079-2086.

Hardie, C. A., M. Wattiaux, M. Dutreuil, R. Gildersleeve, N. S. Keuler, and V. E. Cabrera. 2014. Feeding strategies on certified organic dairy farms in Wisconsin and their effect on milk production and income over feed costs. J. Dairy Sci. 97:4612-4623.

Haugan, J. A., and S. Liaaen-Jensen. 1994. Algal carotenoids 54. Carotenoids of brown algae (Phaeophyceae). Biochem. Syst. Ecol. $22: 31-41$.

Hymes-Fecht, U. C., G. A. Broderick, R. E. Muck, and J. H. Grabber. 2013. Replacing alfalfa or red clover silage with birdsfoot trefoil silage in total mixed rations increases production of lactating dairy cows. J. Dairy Sci. 96:460-469.

IOM. 2001. Iodine. Pages 258-289 in Dietary Reference Intakes. Report of the panel on micronutrients. Food and Nutrition Board. Natl. Acad. Press. Institute of Medicine, Washington, DC.

Kadzere, C. T., M. R. Murphya, N. Silanikove, and E. Maltz. 2002. Heat stress in lactating dairy cows: A review. Livest. Prod. Sci. 77:59-91.

Karatzia, M., E. Christaki, E. Bonos, C. Karatzias, and P. FlorouPaneri. 2012. The influence of dietary Ascophyllum nodosum on haematologic parameters of dairy cows. Ital. J. Anim. Sci. 11:169-173.

Kellogg, D. W., K. Anschutz, and J. Pennington. 2006. Report of research trial with Tasco at Rose Ark Dairy in Arkansas during summer 2005. Arkansas Animal Science Department Report Research Series 545. Univ. of Arkansas, Fayetteville. Accessed Jun. 25, 2014. http://arkansasagnews.uark.edu/545-20.pdf. 
Kraft, J., M. Collomb, P. Möckel, R. Sieber, and G. Jahreis. 2003. Differences in CLA isomer distribution of cow's milk lipids. Lipids 38:657-664.

Kumari, P., M. Kumar, V. Gupta, C. R. K. Reddy, and B. Jha. 2010. Tropical marine macroalgae as potential sources of nutritionally important PUFAs. Food Chem. 120:740-757.

Laurberg, P., S. Andersen, N. Knudsen, L. Ovesen, S. B. Nohr, and I. Bulow Pedersen. 2002. Thiocyanate in food and I in milk: From domestic animal feeding to improved understanding of cretinism. Thyroid 12:897-902.

Leupp, J. L., J. S. Caton, S. A. Soto-Navarro, and G. P. Lardy. 2005. Effects of cooked molasses blocks and fermentation extract or brown seaweed meal inclusion on intake, digestion, and microbial efficiency in steers fed low-quality hay. J. Anim. Sci. 83:29382945.

Licitra, G., T. M. Hernandez, and P. J. Van Soest. 1996. Standardization of procedures for nitrogen fractionation of ruminant feeds. Anim. Feed Sci. Technol. 57:347-358.

MacArtain, P., C. I. R. Gill, M. Brooks, R. Campbell, and I. R. Rowland. 2007. Nutritional value of edible seaweeds. Nutr. Rev. 65:535-543.

Munck, A., P. Guyre, and N. Holbrook. 1984. Physiological functions of glucocorticoids in stress and their relation to pharmacological actions. Endocr. Rev. 5:25-44.

NRC. 2001. Nutrient Requirements of Dairy Cattle. 7th rev. ed. Natl. Acad. Sci., Washington, DC.

Orth, R. 1992. Sample Day and Lactation Report. DHIA 200 FactSheet A-2. Mid-States DRPC, Ames, IA.

Pearce, E. N., S. Pino, X. He, H. R. Bazrafshan, S. L. Lee, and L. E. Braverman. 2004. Sources of dietary iodine: Bread, cows' milk, and infant formula in the Boston area. J. Clin. Endocrinol. Metab. $89: 3421-3424$.

Pennington, J. A. T. 1989. Iodine toxicity. National Technical Information Service, US Department of Commerce, Springfield, VA.

Pompeu, L. B., J. E. Williams, D. E. Spiers, R. L. Weaber, M. R Ellersieck, K. M. Sargent, N. P. Feyerabend, H. L. Vellios, and F. Evans. 2011. Effect of Ascophyllum nodosum on alleviation of heat stress in dairy cows. Prof. Anim. Sci. 27:181-189.

Ragan, M. A., and K. W. Glombitza. 1986. Phlorotannins, brown algal polyphenols. Pages 129-241 in Progress in Phycological Research. Vol. 4. F. E. Round and D. J. Chapman, ed. Biopress Ltd., Bristol, UK

Santschi, D. E., R. Berthiaume, J. J. Matte, A. F. Mustafa, and C. L. Girard. 2005. Fate of supplementary B-vitamins in the gastrointestinal tract of dairy cows. J. Dairy Sci. 88:2043-2054.

Sapolsky, R. M., L. M. Romero, and A. U. Munck. 2000. How do glucocorticoids influence stress responses? Integrating permissive, suppressive, stimulatory, and preparative actions. Endocr. Rev. 21:55-89.

Scott, H. W., and B. A. Dehority. 1965. Vitamin requirements of several cellulolytic rumen bacteria. J. Bacteriol. 89:1169-1175.

Sukhija, P. S., and D. L. Palmquist. 1988. Rapid method for determination of total fatty acid content and composition of feedstuffs and feces. J. Agric. Food Chem. 36:1202-1206.

Tierney, M., A. K. Croft, and M. Hayes. 2010. A review of antihypertensive and antioxidant activity found in macroalgae. Bot. Mar. $53: 387-408$.

Underwood, E. J., and N. F. Suttle. 1999. Iodine. Pages 343-373 in The Mineral Nutrition of Livestock. 3rd ed. CABI Publishing, New York, NY.

USDA-AMS. 2010. National Organic Program: Access to Pasture (Livestock). 7 CFR Part 205, Doc. No. AMS-TM-06-0198; TM05-14FR. RIN 0581-AC57. USDA-Agricultural Marketing Service, Washington, DC.

USDA-USDHHS. 2010. Report of the Dietary Guidelines Advisory Committee on the dietary guidelines for Americans, 2010. USDAUS Department of Health and Human Services, Washington, DC Accessed Jul. 5, 2014. http://www.cnpp.usda.gov/sites/default/ files/dietary_guidelines_for_americans/PolicyDoc.pdf.

Valadares, R. F. D., G. A. Broderick, S. C. Valadares Filho, and M. K. Clayton. 1999. Effect of replacing alfalfa silage with high moisture corn on ruminal protein synthesis estimated from excretion of total purine derivatives. J. Dairy Sci. 82:2686-2696.

Van Keulen, J., and B. A. Young. 1977. Evaluation of acid-insoluble ash as a natural marker in ruminant digestibility studies. J. Anim. Sci. 44:282-287.

Van Soest, P. J., J. B. Robertson, and B. A. Lewis. 1991. Methods for dietary fiber, neutral detergent fiber, and nonstarch polysaccharides in relation to animal nutrition. J. Dairy Sci. 74:3583-3597.

Wahlen, R., L. Evans, J. Turner, and R. Hearn. 2005. The use of collision/reaction cell ICP-MS for the determination of elements in blood and serum samples. Spectroscopy 20:84-89.

Wang, Y., Z. Xu, S. J. Bach, and T. A. McAllister. 2008. Effects of phlorotannins from Ascophyllum nodosum (brown seaweed) on in vitro ruminal digestion of mixed forage or barley grain. Anim. Feed Sci. Technol. 145:375-395.

Wang, Y., Z. Xu, S. J. Bach, and T. A. McAllister. 2009. Sensitivity of Escherichia coli to seaweed (Ascophyllum nodosum) phlorotannins and terrestrial tannins. Asian-Aust. J. Anim. Sci. 22:238-245.

Zimmermann, M. B., Y. Ito, S. Y. Hess, K. Fujieda, and L. Molinari 2005. High thyroid volume in children with excess dietary I intakes. Am. J. Clin. Nutr. 81:840-844. 